\title{
3. RECONSTRUCTED GEOGRAPHIC POSITIONS AND WATER DEPTHS FOR LEG 167 DRILL SITES ${ }^{1}$
}

\author{
Mitchell Lyle ${ }^{2}$
}

\section{INTRODUCTION}

When interpreting the paleoceanographic information preserved in the sedimentary record at ODP drill sites, especially for sediments older than the Pleistocene, it is important to reconstruct the drill site locations and paleodepths to understand the tectonic and geographic effects upon the sediment record. Without such a reconstruction it is possible to misinterpret the sedimentary data. Most of the Leg 167 drill sites are now on the Pacific Plate and have moved in relation to North America. They have also moved in absolute geographic location, with part of the sedimentological signal preserved at each drill site likely resulting from this motion. A record of cooling through time may have been caused partly by the northward drift of the Pacific Plate, whereas changes in the detrital minerals may be a result of Pacific Plate motion with respect to North American river drainages. Some Leg 167 drill sites are on different tectonic plates and have moved in relation to the Pacific Plate sites. Such relative motions may affect the interpretation or reconstruction of offshore transects. Finally, the water depth above each site deepens as ocean crust cools but shallows as sediments are deposited, and the depth of sediment deposition may have changed significantly through time.

It is the intent of this paper to provide an interpretation of tectonic motion at each drill site in both the vertical and horizontal sense to provide the basic data needed to reconstruct geographic patterns of paleoceanographic or paleoclimatic change. Some of the interpretations may be controversial; however, I will try to document my reasoning well enough that the critical assumptions are clear and relatively easy to modify if necessary. Backtrack paths of the drill sites are tabulated in two reference frames: first, relative to the absolute or hotspot reference frame and, second, relative to a fixed North America. Water depths are also tabulated for the same time intervals.

\section{BACKTRACKED DRILL SITE LOCATIONS}

\section{Absolute (Hotspot Reference Frame) Motions}

Site backtracks in the hotspot reference frame are the best available approximation to the absolute position of a drill site through time (Fig. 1). Geographic positions will be accurate if hotspot polar wander is negligible (Gordon, 1987). The hotspot reference frame, however, is not useful for comparing drill site positions to features on the North American Plate unless movement of features on North America are also recalculated using the North America-hotspot reference frame. After the Leg 167 drill sites are backtracked, for example, some of their paleopositions fall within the modern position of North America (Fig. 1). Rather than backtrack every geographic feature within North America, I instead calculated the motion of the sites relative to a fixed North American Plate as discussed in the next section (Fig. 2).

${ }^{1}$ Lyle, M., Koizumi, I., Richter, C., et al., 1997. Proc. ODP, Init. Repts., 167: College Station, TX (Ocean Drilling Program).

${ }^{2}$ Center for Geophysical Investigation of the Shallow Subsurface, Boise State University, 1910 University Drive, Boise, ID 83725, U.S.A
For the hotspot reference frame, I used the Gripp and Gordon (1990) Euler pole positions and angular velocities for 0 to $5 \mathrm{Ma}$; earlier pole positions and angular velocities are from Engebretson et al. (1985). I calculated the colatitude of each drill site from the plate's pole of rotation, assuming a spherical earth and based upon the great circle distance from the pole to the drill site. The colatitude at each drill site was used to calculate the radius with which to multiply the angular velocity and thereby obtain the plate velocity. The orientation of the pole with respect to the drill site and to north was then calculated to provide the directional vector (Fig. 1). I did not calculate plate motions for drill sites that penetrated only Pleistocene sediments (Sites 1015, 1017, and 1019) primarily because the distance that the drill sites moved in the Pleistocene is relatively small and because they all are located in relatively complex tectonic regimes.

For Pacific Plate sites (Sites 1010, 1016, 1018, 1021, and 1022), I used a simple rotation about the Pacific-hotspot pole position. For Site 1020, on the Gorda Plate, I first applied the Pacific-hotspot motion and then used the South Gorda-Pacific relative rotational pole of Riddihough (1984) to correct for motion of the Gorda Plate relative to the Pacific. The pole of rotation concept is not entirely correct for the Gorda Plate because of its deformation (Wilson, 1989), but it is the simplest way to capture most of the motion of the southern Gorda Ridge.

Motions of sites within the California Borderland (Sites 1011, 1012,1013 , and 1014) are the most difficult to determine because of the complex tectonic regime. Nevertheless, it seemed important to make backtrack paths to encourage further efforts to locate their paleopositions. Leg 167 drill sites are superimposed upon the regional tectonic framework in Figure 3. Hornafius et al. (1986) proposed that the Western Transverse Ranges and northern Channel Islands region just east of Site 1017 has been rotated as a rigid block since the beginning of the middle Miocene by transverse motion along the California Margin. The blocks further south, which pushed against the rotated block, should have experienced little rotation but instead have been translated in the direction of Pacific motion relative to North America. By measuring the amount and timing of rotation on the transverse ranges and northern Channel Islands, it is possible to calculate the movement of sites within the outer Borderlands to the west of the San Clemente Island Fault.

Based upon $40^{\circ}$ of rotation in the last 10 million years, or $4 \% \mathrm{~m} . y$., and upon a lever arm of $225 \mathrm{~km}$ to the block on which Site 1014 resides, the site moved relative to the region immediately west of the San Andreas Fault at a rate of $16 \mathrm{~km} / \mathrm{m}$.y. Measured slip rates on the San Andreas and related faults are 34 to $37 \mathrm{~km} / \mathrm{m}$.y. (Humphreys and Weldon, 1991). The total motion between the Pacific Plate and North America in the region of the California Borderlands is $51 \mathrm{~km} / \mathrm{m}$.y., so Pacific Plate motion adequately describes motion experienced by Site 1014

Sites 1011, 1012, and 1013 must have moved somewhat more slowly than Site 1014 to accommodate the rotation of the Western Transverse Ranges. Based upon a lever arm of $170 \mathrm{~km}$, the same $4 \% \mathrm{~m}$.y. rotation rate for the Western Transverse Ranges, and 35 $\mathrm{km} / \mathrm{m}$.y. motion along the San Andreas and related faults, Sites 1011,1012 , and 1013 should have moved with a rate of $47 \mathrm{~km} / \mathrm{m} . \mathrm{y}$. relative to North America, as compared to $51 \mathrm{~km} / \mathrm{m}$.y. for Pacific/ 


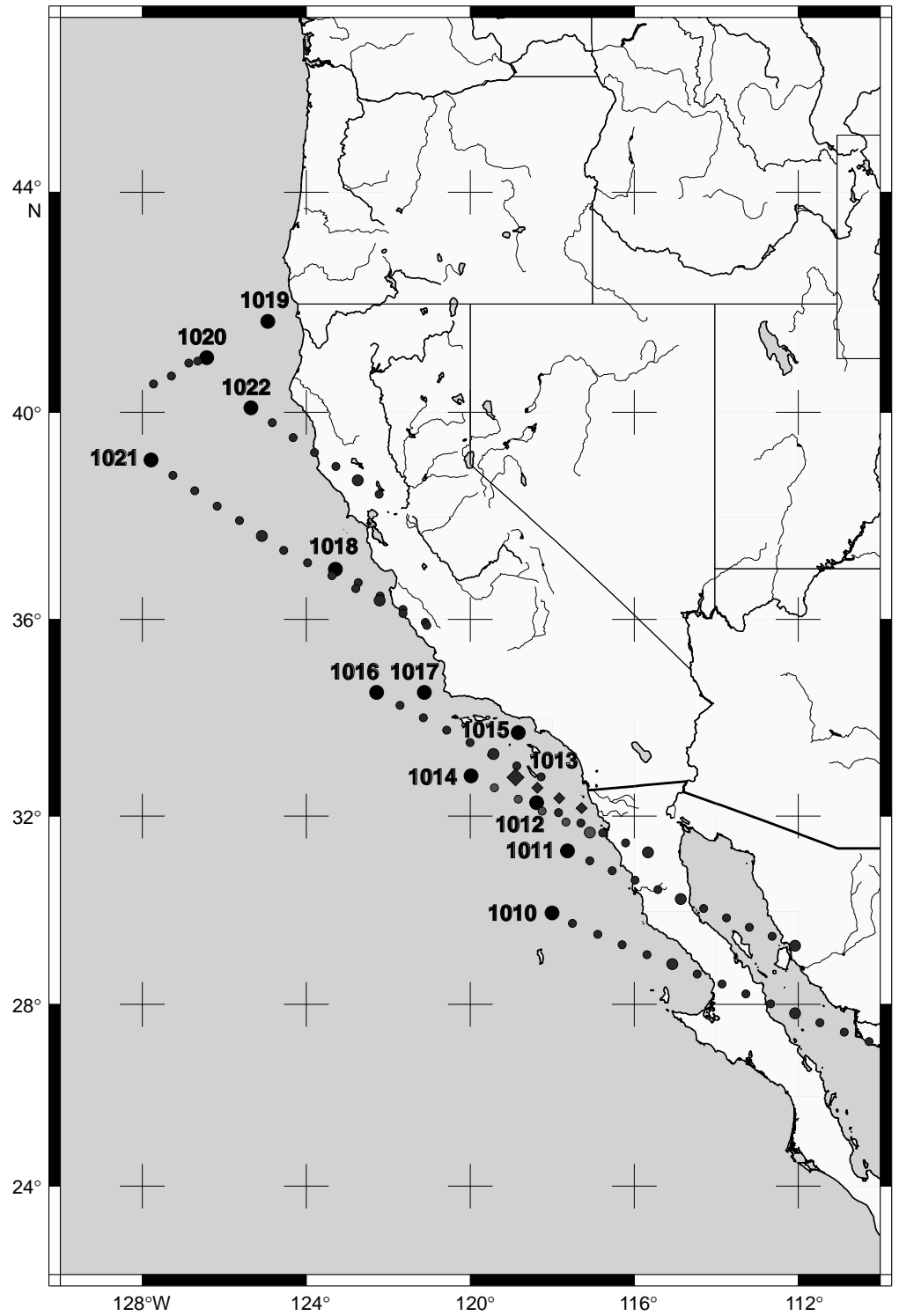

Figure 1. Backtrack paths of Leg 167 drill sites calculated in the hotspot reference frame (see text for methods). North America is positioned in its modern location. Note that many of the backtrack paths intersect the coastline of the modern position of North America.

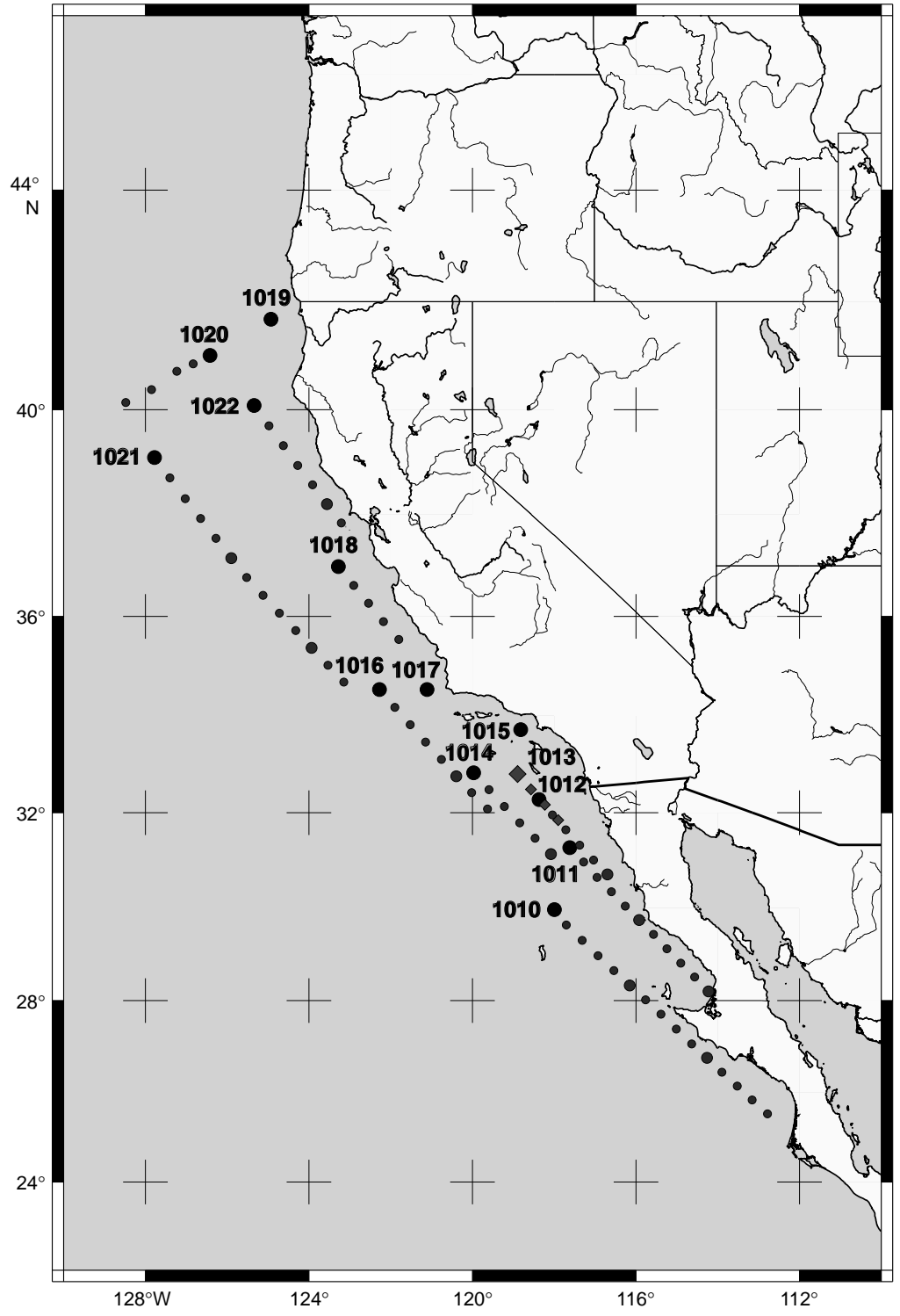

Figure 2. Backtrack paths of Leg 167 drill sites calculated relative to a fixed North American continent, using the Pacific-to-hotspot-to-North America reconstruction circuit. The continental configuration shown is for the modern California Margin, with no movement of either the San Andreas Fault or Baja California. Note how, in a reference frame with a fixed North America, Leg 167 drill sites backtrack along paths parallel to the California Margin. 


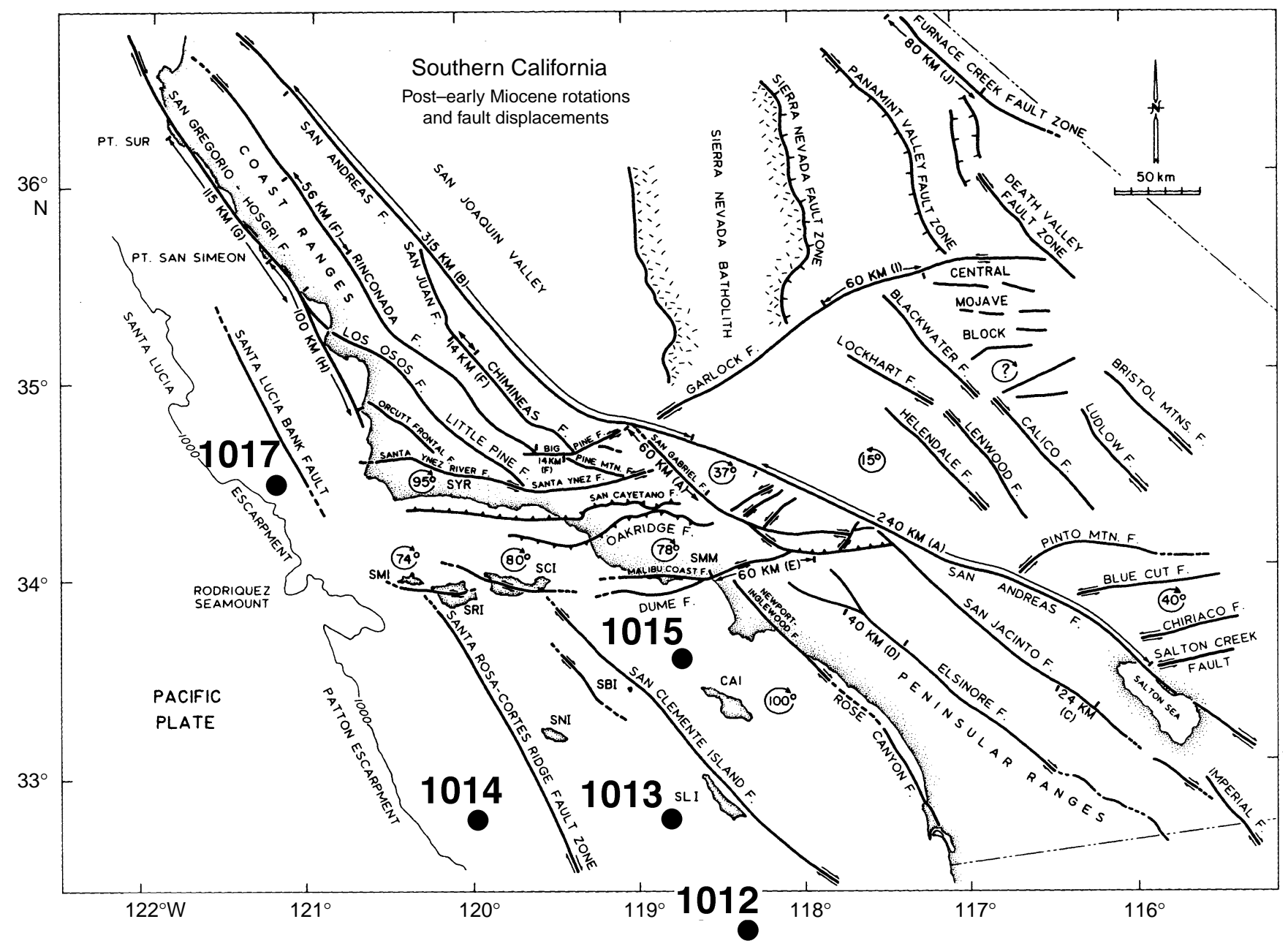

Figure 3. Leg 167 drill sites in the California Borderland region shown with the regional tectonic framework, from Hornafius et al. (1986).

North American relative motion within the Borderland. I have calculated this rate by decreasing the angular rotation with respect to the Pacific-hotspot pole of rotation until Pacific/North American relative motion slowed to $47 \mathrm{~km} / \mathrm{m}$.y. (Table 1 ).

\section{Motions Relative to a Fixed North America}

Another way to present the backtracked positions is with respect to a stable, unmoving North America. Such motion is calculated by subjecting the drill sites first to Pacific-hotspot rotation and then to North America-hotspot rotation. I used the pole position and rotation rates for the North America-hotspot pole from Gripp and Gordon (1990) for all time periods. In the case of the California Borderland sites, I added the North America-hotspot motion to the modified Pacific motion to get the results in Table 1.

Accounting for North American plate motion causes the Leg 167 backtrack paths to parallel the California continental margin rather than intersect it (Fig. 2). All Leg 167 sites, when viewed from stable North America, moved northwestward parallel to the coastline through time. These motions relative to a fixed North America will be more useful to compare between drill site positions and features on North America, because they are expressed relative to the latitude and longitude of the modern position of North America. It is important to remember, however, that the absolute positions (the actual latitude and longitude) are misrepresented and should not be used for reconstruction of climate gradients.

\section{PALEODEPTH CALCULATIONS}

Each of the Leg 167 drill sites has changed depth through time primarily as a result of three factors - thermal subsidence of the cooling crust, buildup of sediment on top of the crust, and isostatic subsidence as the sediment pile thickens. In regions with active vertical tectonics, there also can be tectonic subsidence or uplift. I have constructed an empirical subsidence model for each site backtracked in the last section (Table 2; Sites 1010, 1011, 1012, 1013, 1014, 1016, $1018,1020,1021)$ based only upon thermal subsidence and sedimentation. This model is not strictly correct for any location with significant tectonic complications. Consistent subsidence behavior of the California Borderland sites (Sites 1011, 1012, 1013, and 1014), however, suggests that the different Borderland basins did not experience unique tectonic histories.

The model is based on the thermal subsidence model of Rea and Leinen (1986):

$$
Z=Z_{a}+K t^{1 / 2}
$$

where $Z$, the paleodepth, is a function of the original ridge axis depth $\left(Z_{a}\right)$ and the thermal subsidence, represented by the square root of time since the crust was formed $(t)$, multiplied by an empirical thermal subsidence coefficient, $K$. I added to this model terms for sedimentation: first, the loss of depth caused by the buildup of sedi- 
Table 1. Backtrack paths for Leg 167 drill sites, with respect to the hotspot reference frame and fixed North America reference frame.

\begin{tabular}{|c|c|c|c|c|c|}
\hline \multirow[b]{2}{*}{ Site } & \multirow[b]{2}{*}{$\begin{array}{l}\text { Age } \\
\text { (Ma) }\end{array}$} & \multicolumn{2}{|c|}{$\begin{array}{c}\text { Hotspot reference } \\
\text { frame }\end{array}$} & \multicolumn{2}{|c|}{$\begin{array}{l}\text { Fixed North America } \\
\text { reference frame }\end{array}$} \\
\hline & & $\begin{array}{l}\text { Latitude } \\
\left({ }^{\circ} \mathrm{N}\right)\end{array}$ & $\begin{array}{c}\text { Longitude } \\
\left({ }^{\circ} \mathrm{W}\right)\end{array}$ & $\begin{array}{l}\text { Latitude } \\
\left({ }^{\circ} \mathrm{N}\right)\end{array}$ & $\begin{array}{c}\text { Longitude } \\
\left({ }^{\circ} \mathrm{W}\right)\end{array}$ \\
\hline 1010 & $\begin{array}{r}0 \\
1 \\
2 \\
3 \\
4 \\
5 \\
6 \\
7 \\
8 \\
9 \\
10 \\
11 \\
12 \\
13 \\
14\end{array}$ & $\begin{array}{l}29.97 \\
29.74 \\
29.51 \\
29.29 \\
29.08 \\
28.87 \\
28.66 \\
28.44 \\
28.23 \\
28.02 \\
27.81 \\
27.61 \\
27.40 \\
27.20 \\
27.01\end{array}$ & $\begin{array}{l}118.10 \\
117.50 \\
116.89 \\
116.29 \\
115.68 \\
115.07 \\
114.46 \\
113.86 \\
113.27 \\
112.67 \\
112.07 \\
111.47 \\
110.87 \\
110.27 \\
109.67\end{array}$ & $\begin{array}{l}29.97 \\
29.64 \\
29.31 \\
28.98 \\
28.66 \\
28.34 \\
28.03 \\
27.71 \\
27.39 \\
27.07 \\
26.76 \\
26.45 \\
26.14 \\
25.83 \\
25.52\end{array}$ & $\begin{array}{l}118.10 \\
117.71 \\
117.32 \\
116.93 \\
116.54 \\
116.16 \\
115.77 \\
115.39 \\
115.02 \\
114.64 \\
114.27 \\
113.90 \\
113.53 \\
113.16 \\
112.79\end{array}$ \\
\hline 1011 & $\begin{array}{r}0 \\
1 \\
2 \\
3 \\
4 \\
5 \\
6 \\
7 \\
8 \\
9 \\
10\end{array}$ & $\begin{array}{l}31.28 \\
31.07 \\
30.86 \\
30.66 \\
30.46 \\
30.26 \\
30.06 \\
29.86 \\
29.66 \\
29.47 \\
29.27\end{array}$ & $\begin{array}{l}117.63 \\
117.08 \\
116.53 \\
115.98 \\
115.42 \\
114.86 \\
114.30 \\
113.74 \\
113.19 \\
112.63 \\
112.07\end{array}$ & $\begin{array}{l}31.28 \\
30.97 \\
30.65 \\
30.35 \\
30.04 \\
29.74 \\
29.44 \\
29.13 \\
28.82 \\
28.52 \\
28.21\end{array}$ & $\begin{array}{l}117.63 \\
117.29 \\
116.96 \\
116.61 \\
116.27 \\
115.93 \\
115.58 \\
115.25 \\
114.91 \\
114.57 \\
114.23\end{array}$ \\
\hline 1012 & $\begin{array}{l}0 \\
1 \\
2 \\
3 \\
4 \\
5\end{array}$ & $\begin{array}{l}32.28 \\
32.07 \\
31.86 \\
31.65 \\
31.44 \\
31.24\end{array}$ & $\begin{array}{l}118.38 \\
117.84 \\
117.30 \\
116.76 \\
116.21 \\
115.66\end{array}$ & $\begin{array}{l}32.28 \\
31.96 \\
31.65 \\
31.33 \\
31.02 \\
30.71\end{array}$ & $\begin{array}{l}118.38 \\
118.05 \\
117.72 \\
117.38 \\
117.04 \\
116.70\end{array}$ \\
\hline 1013 & $\begin{array}{l}0 \\
1 \\
2 \\
3\end{array}$ & $\begin{array}{l}32.80 \\
32.58 \\
32.37 \\
32.16\end{array}$ & $\begin{array}{l}118.90 \\
118.36 \\
117.83 \\
117.29\end{array}$ & $\begin{array}{l}32.80 \\
32.48 \\
32.16 \\
31.84\end{array}$ & $\begin{array}{l}118.90 \\
118.57 \\
118.23 \\
117.90\end{array}$ \\
\hline 1014 & $\begin{array}{l}0 \\
1 \\
2 \\
3\end{array}$ & $\begin{array}{l}32.83 \\
32.59 \\
32.35 \\
32.11\end{array}$ & $\begin{array}{l}119.98 \\
119.40 \\
118.82 \\
118.24\end{array}$ & $\begin{array}{l}32.83 \\
32.49 \\
32.14 \\
31.80\end{array}$ & $\begin{array}{l}119.98 \\
119.60 \\
119.22 \\
118.85\end{array}$ \\
\hline
\end{tabular}

ments, and, second, the depth gain resulting from isostatic subsidence under the sediment load. I calculated the isostatic subsidence by assuming that average mantle rock has a density of $3.2 \mathrm{gm} / \mathrm{cm}^{3}$, whereas Leg 167 sediments have an average density of $1.7 \mathrm{gm} / \mathrm{cm}^{3}$, and seawater has a density of $1.0 \mathrm{gm} / \mathrm{cm}^{3}$. During isostatic subsidence, the added mass will displace an equivalent mass of dense mantle, and the vertical change can be calculated by the equivalent length of the mass columns, or

$$
Z_{i}=H_{s}\left(\rho_{s}-\rho_{w}\right) / \rho_{m}
$$

where $Z_{i}$ is the isostatic subsidence, $H_{s}$ is the height of the sediment column, $\left(\rho_{s}-\rho_{w}\right)$ is the difference in density between the average sediment and water, and $\rho_{m}$ is the density of the underlying mantle. Based upon the densities above, the isostatic subsidence is $22 \%$ of the height of the sediment column. The final subsidence model is given below:

$$
Z=Z_{a}+K t^{1 / 2}-H_{s}+0.22 H_{s}
$$

I calculated the empirical subsidence coefficient $K$ by assuming an original crustal depth, $Z_{a}$, and calculating the modern unloaded basement depth. Then I solved for $K$. These data are also included in Table 2. For sites on Pacific Plate ocean crust (Sites 1010, 1016, and 1021), I assumed that the original ridge axis depth, $Z_{a}$, was 2800 mbsl. For Site 1018, which was located next to a seamount, I assumed an original crustal depth of $2300 \mathrm{mbsl}$. All of these sites have subsid-

\begin{tabular}{|c|c|c|c|c|c|}
\hline \multirow[b]{2}{*}{ Site } & \multirow[b]{2}{*}{$\begin{array}{l}\text { Age } \\
\text { (Ma) }\end{array}$} & \multicolumn{2}{|c|}{$\begin{array}{l}\text { Hotspot reference } \\
\text { frame }\end{array}$} & \multicolumn{2}{|c|}{$\begin{array}{l}\text { Fixed North America } \\
\text { reference frame }\end{array}$} \\
\hline & & $\begin{array}{l}\text { Latitude } \\
\left({ }^{\circ} \mathrm{N}\right)\end{array}$ & $\begin{array}{l}\text { Longitude } \\
\left({ }^{\circ} \mathrm{W}\right)\end{array}$ & $\begin{array}{l}\text { Latitude } \\
\left({ }^{\circ} \mathrm{N}\right)\end{array}$ & $\begin{array}{l}\text { Longitude } \\
\left({ }^{\circ} \mathrm{W}\right)\end{array}$ \\
\hline & $\begin{array}{l}4 \\
5\end{array}$ & $\begin{array}{l}31.88 \\
31.66\end{array}$ & $\begin{array}{l}117.66 \\
117.08\end{array}$ & $\begin{array}{l}31.47 \\
31.14\end{array}$ & $\begin{array}{l}118.47 \\
118.09\end{array}$ \\
\hline 1016 & $\begin{array}{l}0 \\
1 \\
2 \\
3 \\
4 \\
5 \\
6 \\
7\end{array}$ & $\begin{array}{l}34.54 \\
34.28 \\
34.02 \\
33.77 \\
33.52 \\
33.28 \\
33.04 \\
32.81\end{array}$ & $\begin{array}{l}122.28 \\
121.71 \\
121.14 \\
120.57 \\
120.00 \\
119.43 \\
118.86 \\
118.27\end{array}$ & $\begin{array}{l}34.54 \\
34.18 \\
33.82 \\
33.47 \\
33.11 \\
32.77 \\
32.43 \\
32.09\end{array}$ & $\begin{array}{l}122.28 \\
121.90 \\
121.52 \\
121.15 \\
120.77 \\
120.39 \\
120.02 \\
119.64\end{array}$ \\
\hline 1018 & $\begin{array}{l}0 \\
1 \\
2 \\
3 \\
4\end{array}$ & $\begin{array}{l}36.99 \\
36.72 \\
36.46 \\
36.20 \\
35.94\end{array}$ & $\begin{array}{l}123.28 \\
122.73 \\
122.19 \\
121.64 \\
121.09\end{array}$ & $\begin{array}{l}36.99 \\
36.62 \\
36.26 \\
35.90 \\
35.54\end{array}$ & $\begin{array}{l}123.28 \\
122.91 \\
122.54 \\
122.18 \\
121.81\end{array}$ \\
\hline 1020 & $\begin{array}{l}0 \\
1 \\
2 \\
3 \\
4\end{array}$ & $\begin{array}{l}41.00 \\
40.95 \\
40.91 \\
40.67 \\
40.53\end{array}$ & $\begin{array}{l}126.43 \\
126.64 \\
126.86 \\
127.28 \\
127.72\end{array}$ & $\begin{array}{l}41.00 \\
40.86 \\
40.72 \\
40.38 \\
40.14\end{array}$ & $\begin{array}{l}126.43 \\
126.84 \\
127.24 \\
127.86 \\
128.49\end{array}$ \\
\hline 1021 & $\begin{array}{r}0 \\
1 \\
2 \\
3 \\
4 \\
5 \\
6 \\
7 \\
8 \\
9 \\
10 \\
11 \\
12\end{array}$ & $\begin{array}{l}39.10 \\
38.80 \\
38.51 \\
38.21 \\
37.93 \\
37.64 \\
37.36 \\
37.11 \\
36.86 \\
36.61 \\
36.37 \\
36.12 \\
35.88\end{array}$ & $\begin{array}{l}127.78 \\
127.25 \\
126.71 \\
126.17 \\
125.62 \\
125.08 \\
124.54 \\
123.96 \\
123.37 \\
122.79 \\
122.21 \\
121.64 \\
121.06\end{array}$ & $\begin{array}{l}39.10 \\
38.70 \\
38.31 \\
37.92 \\
37.54 \\
37.15 \\
36.77 \\
36.42 \\
36.07 \\
35.72 \\
35.38 \\
35.03 \\
34.69\end{array}$ & $\begin{array}{l}127.78 \\
127.40 \\
127.03 \\
126.65 \\
126.27 \\
125.90 \\
125.53 \\
125.12 \\
124.73 \\
124.33 \\
123.93 \\
123.54 \\
123.15\end{array}$ \\
\hline 1022 & $\begin{array}{l}0 \\
1 \\
2 \\
3 \\
4 \\
5 \\
6\end{array}$ & $\begin{array}{l}40.08 \\
39.80 \\
39.52 \\
39.24 \\
38.97 \\
38.71 \\
38.44\end{array}$ & $\begin{array}{l}125.34 \\
124.82 \\
124.31 \\
123.79 \\
123.27 \\
122.74 \\
122.22\end{array}$ & $\begin{array}{l}40.08 \\
39.70 \\
39.32 \\
38.95 \\
38.57 \\
38.21 \\
37.84\end{array}$ & $\begin{array}{l}125.34 \\
124.98 \\
124.63 \\
124.27 \\
123.92 \\
123.57 \\
123.21\end{array}$ \\
\hline
\end{tabular}
ence coefficients in the range of $218-314 \mathrm{~m} /(\mathrm{m} . \mathrm{y} .)^{1 / 2}$.
Site 1020, on the Gorda Ridge, had to pass over an axial valley wall at a depth of about $2000 \mathrm{mbsl}$. To compensate for this, I assumed an equivalent ridge axis depth (i.e., no rift valley) of $1800 \mathrm{mbsl}$. The thermal subsidence coefficient for this site is larger, $645 \mathrm{~m} /(\mathrm{m} . \mathrm{y} .)^{1 / 2}$, and probably subsumes some vertical tectonism associated with the formation of the rift valley. The resulting paleodepth profile in Table 2 is supported by changes in the benthic foraminiferal community through time. The oldest benthic assemblages are lower middle bathyal and those above $256 \mathrm{mbsf}$ at the site are lower bathyal, indicating a subsidence of 500-1000 $\mathrm{m}$ for the lowermost part of the core.

The California Borderland paleodepth profiles are speculative. They were modeled assuming that acoustic basement, estimated from seismic reflection, was at sea level at $12 \mathrm{Ma}$. Next, $K$ was calculated by using the unloaded crustal depth at each site. The thermal subsidence coefficients for Sites 1011-1014 grouped fairly tightly, 523$654 \mathrm{~m} /(\mathrm{m} . \mathrm{y} .)^{1 / 2}$, suggesting that all the outer borderland basins that were drilled on Leg 167 have a similar subsidence history. It is worth noting that the assumptions affect paleodepth most strongly prior to $5 \mathrm{Ma}$, so the most care should be taken for older sections.

Site 1022, just south of the Mendocino fracture zone, was assumed to be at sea level at $30 \mathrm{Ma}$, and its paleodepth profile was calculated in a similar manner to the California Borderland sites.

\section{Implications of Leg 167 Paleodepth Profiles}

One of the most striking features of the Leg 167 paleodepth profiles is the strong influence of high sedimentation rates upon the depth profiles. Since $4 \mathrm{Ma}$, for example, the paleodepth of Site 1018 
Table 2. Calculated paleodepths below sea level corrected for subsidence and sedimentation.

\begin{tabular}{|c|c|c|c|c|c|c|c|}
\hline Site & $\begin{array}{l}\text { Age } \\
\text { (Ma) }\end{array}$ & $\begin{array}{c}\text { Sediment } \\
\text { thickness } \\
(\mathrm{m})\end{array}$ & $\begin{array}{l}\text { Total sediment } \\
\text { thickness } \\
(\mathrm{m})\end{array}$ & $\begin{array}{l}\text { Crustal age } \\
\text { (Ma) }\end{array}$ & $\begin{array}{l}\text { Unloaded } \\
\text { crustal depth } \\
\text { (mbsl) }\end{array}$ & $\begin{array}{c}K \\
\text { (subsidence } \\
\text { coefficient) }\end{array}$ & $\begin{array}{l}\text { Paleodepth } \\
\quad(\mathrm{mbsl})\end{array}$ \\
\hline 1010 & $\begin{array}{r}0 \\
1 \\
2 \\
3 \\
4 \\
5 \\
6 \\
7 \\
8 \\
9 \\
9 \\
10 \\
11 \\
12 \\
13 \\
14\end{array}$ & $\begin{array}{r}0 \\
11 \\
16 \\
22 \\
43 \\
54 \\
68 \\
77 \\
87 \\
102 \\
112 \\
126 \\
132 \\
162 \\
195\end{array}$ & 209 & 14.5 & 3629 & 218 & $\begin{array}{l}3466 \\
3450 \\
3420 \\
3390 \\
3380 \\
3350 \\
3330 \\
3290 \\
3260 \\
3230 \\
3190 \\
3140 \\
3080 \\
3030 \\
2940\end{array}$ \\
\hline 1011 & $\begin{array}{l}0 \\
1 \\
2 \\
3 \\
4 \\
5 \\
6 \\
7 \\
8 \\
9\end{array}$ & $\begin{array}{r}0 \\
31 \\
70 \\
106 \\
133 \\
148 \\
167 \\
185 \\
213 \\
263\end{array}$ & 276 & 12.0 & 2235 & 645 & $\begin{array}{l}2020 \\
1950 \\
1880 \\
1800 \\
1710 \\
1610 \\
1490 \\
1370 \\
1240 \\
1110\end{array}$ \\
\hline 1012 & $\begin{array}{l}0 \\
1 \\
2 \\
3 \\
4 \\
5\end{array}$ & $\begin{array}{r}0 \\
62 \\
130 \\
207 \\
265 \\
272\end{array}$ & $630^{*}$ & 12.0 & 2263 & 653 & $\begin{array}{l}1772 \\
1720 \\
1670 \\
1630 \\
1560 \\
1450\end{array}$ \\
\hline 1013 & $\begin{array}{l}0 \\
1 \\
2 \\
3\end{array}$ & $\begin{array}{r}0 \\
65 \\
107 \\
142\end{array}$ & $900 *$ & 12.0 & 2266 & 654 & $\begin{array}{l}1564 \\
1730 \\
1660 \\
1580\end{array}$ \\
\hline 1014 & $\begin{array}{l}0 \\
1 \\
2 \\
3 \\
4 \\
5\end{array}$ & $\begin{array}{r}0 \\
80 \\
158 \\
298 \\
344 \\
362\end{array}$ & $830 *$ & 12.0 & 1813 & 523 & $\begin{array}{l}1166 \\
1150 \\
1130 \\
1150 \\
1100 \\
1020\end{array}$ \\
\hline 1016 & $\begin{array}{l}0 \\
1 \\
2 \\
3 \\
4 \\
5 \\
6 \\
7\end{array}$ & $\begin{array}{r}0 \\
34 \\
65 \\
132 \\
163 \\
167 \\
205 \\
300\end{array}$ & $440^{*}$ & 22.5 & 4178 & 291 & $\begin{array}{l}3835 \\
3830 \\
3830 \\
3840 \\
3840 \\
3800 \\
3800 \\
3840\end{array}$ \\
\hline 1018 & $\begin{array}{l}0 \\
1 \\
2 \\
3 \\
4\end{array}$ & $\begin{array}{l}0 \\
105 \\
235 \\
365 \\
505 * *\end{array}$ & $950 *$ & 20.0 & 3217 & 205 & $\begin{array}{l}2476 \\
2530 \\
2610 \\
2690 \\
2770\end{array}$ \\
\hline 1020 & $\begin{array}{l}0 \\
1 \\
2 \\
3 \\
4\end{array}$ & $\begin{array}{r}0 \\
87 \\
173 \\
228 \\
279\end{array}$ & 279 & 5.1 & 3256 & 645 & $\begin{array}{l}3038 \\
2960 \\
2850 \\
2690 \\
2480\end{array}$ \\
\hline 1021 & $\begin{array}{r}0 \\
1 \\
2 \\
3 \\
4 \\
5 \\
6 \\
7 \\
8 \\
9 \\
10 \\
11 \\
12\end{array}$ & $\begin{array}{r}0 \\
31 \\
59 \\
91 \\
118 \\
147 \\
174 \\
195 \\
226 \\
243 \\
277 \\
286 \\
299\end{array}$ & $380 *$ & 29.6 & 4508 & 314 & $\begin{array}{l}4212 \\
4210 \\
4200 \\
4190 \\
4180 \\
4180 \\
4160 \\
4150 \\
4140 \\
4120 \\
4110 \\
4080 \\
4050\end{array}$ \\
\hline 1022 & $\begin{array}{l}0 \\
1 \\
2 \\
3 \\
4 \\
5\end{array}$ & $\begin{array}{r}0 \\
0 \\
0 \\
88 \\
200 \\
310\end{array}$ & $560^{*}$ & 30.0 & 2363 & 431 & $\begin{array}{l}1926 \\
1880 \\
1840 \\
1870 \\
1920 \\
1960\end{array}$ \\
\hline
\end{tabular}

Note: $*=$ estimated from seismic reflection profiles, $* *=$ interpolated beyond drill depth. 
shallows rapidly by about $300 \mathrm{~m}$ because of the high average sedimentation rate. Sites 1011-1014 in the California Borderland deepen only slightly in the past $5 \mathrm{~m}$.y. despite high crustal subsidence, whereas Site 1016 stays within $40 \mathrm{~m}$ of its modern depth for the last $7 \mathrm{~m}$.y. Only Site 1020 experiences a rapid deepening during its history despite high sedimentation rates.

\section{CONCLUSIONS}

I have reconstructed geographic positions and water depths for most of the Leg 167 drill sites. Care was taken in the reconstructions, but it is important to realize, especially for the drill sites in the California Borderland (Sites 1011-1014), that unmodeled processes could significantly affect the vertical and horizontal movements of the sediment basins. These reconstructions, however, should be adequate for primary geographic reconstructions for paleoceanography on the California Margin.

\section{REFERENCES}

Engebretson, D.C., Cox, A., and Gordon, R.G., 1985. Relative Motions Between Oceanic and Continental Plates in the Pacific Basin. Spec. Pap.-Geol. Soc. Am., 206.
Gordon, R.G., 1987. Polar wandering and paleomagnetism. Аnnu. Rev. of Earth Planet. Sci. 15:567-593.

Gripp, A.E., and Gordon, R.G., 1990. Current plate velocities relative to the hotspots incorporating the NUVEL-1 global plate motion model. Geophys. Res. Lett., 17:1109-1112.

Hornafius, J.S., Luyendyk, B.P., Terres, R.R., and Kamerling, M.J., 1986. Timing and extent of Neogene tectonic rotation in the western Transverse Ranges, California. Geol. Soc. Amer. Bull., 97:1476-1487.

Humphreys, E.D., and Weldon, R.J., 1991. Kinematic constraints on the rifting of Baja California. In Dauphin, J.P., and Simoneit, B.R.T. (Eds.), The Gulf and Peninsular Province of the Californias. AAPG Mem., 47:217231.

Rea, D.K., and Leinen, M., 1986. Crustal subsidence and calcite deposition in the South Pacific Ocean. In Leinen, M., Rea, D.K., et al., Init. Repts. DSDP, 92: Washington (U.S. Govt. Printing Office), 299-303.

Riddihough, R.P., 1984. Recent movements of the Juan de Fuca plate system. J. Geophys. Res., 89:6980-6994.

Wilson, D.S., 1989. Deformation of the so-called Gorda Plate. J. Geophys. Res., 94:3065-3075.

\section{Ms 167IR-103}

